\title{
PHYSICO-CHEMICAL QUALITY OF POTABLE WATER OF VARANASI CITY OF DIFFERENT SOURCES
}

\author{
ALOK KUMAR SINGH ${ }^{1}$
}

Department of Botany, C. M. P. P.G. College, Allahabad, Uttar Pradesh, India

\begin{abstract}
Water an elixir of life. It is needed for drinking, producing food and running industries, generating power and many such other activities. The safety of drinking water is important for the health. The safety of drinking water is affected by various contaminants which included physico-chemical and microbiological. Such contaminants cause serious health problems. During the study it was found that maximum number of physical and chemical parameter were within the desirable limit, as suggested by WHO (1984). The objective of the present research is to provide information on the physicochemical characteristics of Potable water of Varanasi city of different sources in order to discuss it's suitability for human consumption. Physicochemical and biochemical aspects of the water have been investigated to assess the quality of water.
\end{abstract}

KEYWORDS: Potable water, Varanasi, Physico-chemical, Temperature, BOD, DO

Water an elixir of life, is also the most important and essential component of the protoplasm. Thus life and water are inseparable faces of the same coin. It is needed for drinking, producing food and running industries, generating power and many such other activities. Moreover, the limited available clear and unpolluted water is being continuously polluted by human being and the availability of clear water has become a great problem for human being as well as for different kinds of plants and animals. Over 2 billion people or half of the world's population have suffered from diseased due to drinking polluted water (Barbas, 1986).Ground water is one of the most important sources of drinking water in India. The most important source of drinking water for about 70 percent of Indian population is groundwater and is considered less polluted. But lack of sanitation, improper waste disposal, faulty well construction and lack of water source protection increase ground water contamination and 40 per cent or more of the disease outbreaks were attributed to polluted groundwater consumption. Naturally first serious scientific information on water quality appeared from Germany. Water is an important substance required by all living organisms and for all anthropogenic activities (Khatri, 1985; Dagankar and Saksena, 1992; Kumar et al., 2002).

Hantge (1978) has studies the pollution of Nahe river and its tributaries in Germany and showed that high pollution level at certain points were due to pouring of domestic and industrial wastes. The assessment of pollution aspects of various river water has been reported (Palmer, 1969). Many scientists Ganpati and Alikunhi (1950), Ganpati and Chacko (1957), Motawani et al., (1956) and
David (1959) observed that water of the river Ganga was heavily polluted, endangered the health of the people, and was detrimental to the fish life. Sengar et al., (1985) have studied the pollution load in the river Yamuna at Agra. Verma and Mathur, (1971); and Kudesia and Sharma (1981) have conducted several studies on the pollution of the river water in western Uttar Pradesh and observed great changes in the physico-chemical characteristics and further studied its effect on the aquatic life. A number of workers (Deshmukh et al., 1964; Ray et al., 1966; Rajgopalan et al., 1970; Sangu et al., 1984; Singh et al., 1985) have analysed and discussed the physico-chemical characteristics of river water at various places. Shukla et al., (1988) reported physico-chemical and bacteriological population of river Varuna at the sampling sites. The discharge of sewage and industrial effluents in river Varuna decreases for transparency, DO and increases for BOD, COD, acidity, alkalinity, nitrate, phosphate and bacterial population. Trivedy (1988) also reviewed the water quality of different rivers out of which river the Yamuna is heavily polluted by sewage sludge and industrial wastes.

Gowd et al., (1999) reported the seasonal variation of physical, chemical and biological quality of water in a tropical Kalyani reservoir near Tirupati. The result indicates that there is a wide seasonal variation in the quality of water. Mohamed et al., (2000) studied the various systems of obstruction, treatment and distribution in the water works of Tiruchirapalli Corporation and the physico-chemical parameters of the water samples tested are well within the Water Quality Standards of WHO, ICMR, ISI and CPHEED. Dwivedi (2000) a water quality survey of River 
SINGH: PHYSICO-CHEMICAL QUALITY OF POTABLE WATER OF VARANASI CITY OF...

Ganga at Varanasi was conducted to assess the water quality fluctuations in terms of important physico-chemical and bacteriological variables.

Hussain and Ahmad (2002) measured water quality for Pachin River for the three major flow periods. The $\mathrm{pH}$, temperature, conductivity, $\mathrm{DO}, \mathrm{COD}, \mathrm{PO}_{4}$, total hardness and alkalinity shows variation for different flow periods. Singh and Singh (2003) analyses physico-chemical quality of River Ami in relation to discharge of paper mill effluent. The high degree of water quality degradation is reflected by the changes in values of BOD, COD, DO, nitrogen content and chlorides etc in downstream. Rajurkar et al., (2003) invested the physico-chemical and biological quality of river Umshyrpi at Shillong. The study reveals that physico-chemical parameters are within the permissible limit that indicates unpotability of water for drinking purposes. Correlation between biochemical oxygen demand (BOD) and Chemical oxygen demand (COD) has been reported by (Kannan and Rajsekharan, 1991). Correlation among water quality parameters of groundwater, rivers water and industrial effluent has been reported by several workers (Nagarajan et al., 1992; Rao, 1993). When correlation exists between various water quality parameters it would give more idea about water quality parameters and the dependence between them. Balasankar et al., 1999, reported physico-chemical characteristic of groundwater samples collected at different locations in and around Guddalore SIPCOT. Dasgupta et al., 2000, monitored 29 physico-chemical parameters of water from 8 sampling point of Raj gangapur municipal area and the value obtained were correlated with standards prescribed by Bureau Of Indian Standards (BIS), Indian Council Of Medical research (ICMR) and World Health Organization (WHO).

\section{MATERIALS AND METHODS}

Total six sampling sites in Varanasi city were selected for the study. Site I and Site II were selected along the bank of the Ganges river. Site I, named as University Ghat (Same Ghat) and Sit II, named as Assi Ghat is at about $1 \mathrm{~km}$ downstream from the site first. Site III is a well situated in the same ward around which a large number of people take bath and wash their clothes daily. They also use this water for drinking. The Well is about 40 feet in depth. Site IV is a cemented tank situated in a house of the ward Karaundi (Varanasi) at a height of about $8 \mathrm{M}$.
Site $\mathrm{V}$ is a hand pump situated in the ward Sunderpur (Varanasi).

Site VI is situated in Sunderpur ward (Varanasi). There is a common water tap meant for general public. The source of the water is river Ganges supplied in the city by Jal Nigam of Varanasi city.

Samples of water were collected from all the sites at monthly interval in the third week of each month from Jan. 2000 to Dec. 2000. Five hundred $\mathrm{ml}$ reagent bottles with ground glass stopper were used after sterilization in hot air over at $160^{\circ} \mathrm{C}$ for one hour. The water samples were brought into laboratory in the boxes for the analysis of various physico-chemical i.e. $\mathrm{pH}$, acidity, total alkalinity, dissolved oxygen (DO), and biochemical oxygen demand (BOD). The collection preservation and analysis of these samples were carried out following the procedure prescribed by APHA (1989).

\section{RESULTS}

Water samples were analyzed for temperature, $\mathrm{pH}$, dissolved oxygen (DO), Biological oxygen demand (BOD), Total alkalinity and Total acidity.

The Temperature varied from 18 to $25^{\circ} \mathrm{C}$ at site I 19 to $24^{\circ} \mathrm{C}$ at site II, 23 to $26^{\circ} \mathrm{C}$ at site III, 22 to $30^{\circ} \mathrm{C}$ at site IV, 22 to $26^{\circ} \mathrm{C}$ at site $\mathrm{V}$ and 20 to $23^{\circ}$ Cat site six. During the period of investigation the gradual rise in water temperature was recorded from March onwards reaching maximum in summer (June) and subsequently decreasing to minimum in winter. (Table 1)

Table 1: Monthly Variation in Temperature

\begin{tabular}{|c|c|c|c|}
\hline Site & Jan-Apr & May-Aug & Sep-Dec \\
\hline $\mathbf{1}$ & 18.6 & 26.7 & 24.6 \\
\hline $\mathbf{2}$ & 18.5 & 26.8 & 24.8 \\
\hline $\mathbf{3}$ & 23.4 & 25.7 & 24.2 \\
\hline $\mathbf{4}$ & 21.5 & 29.7 & 25.9 \\
\hline $\mathbf{5}$ & 22.3 & 24.5 & 22.9 \\
\hline $\mathbf{6}$ & 19.8 & 22.3 & 20 \\
\hline
\end{tabular}

In the present study the $\mathrm{pH}$ values of water were seconded from a maximum of 8.02 at site I during MayAug. and to minimum of 7.12 at site III in during Jan-Apr.

The mean range of $\mathrm{pH}$ of the water in different periods of the year are shown in table 2. The $\mathrm{pH}$ varied 
from 7.75 to 8.02 at site I, 7.77 to 7.8 at site II, 7.12 to 7.57 at site III, 7.2 to 7.57 at site IV, 7.5 to 7.75 at site $\mathrm{V}$ and 7.15 to 7.35 at site VI (Table 2).

The DO varied between 6.2 to $9.3 \mathrm{mg} / \mathrm{L}$ during the year. The lowest DO of 6.2 was observed during Jan-Apr. at site $\mathrm{V}$ and the highest $(9.3 \mathrm{mg} / \mathrm{L})$ during Jan-Apr at site IV. The mean seasonal value ranged from 86.22 to 8.32 at site I, 6.95 to 8.45 at site II, 6.2 to 7.15 at site $\mathrm{V}$ and 7.62 to 8.2 at site IV. In general the value of dissolved oxygen were recorded higher in winter and lower in summer months. (Table 3).

Table 2: Monthly Variation in pH

\begin{tabular}{|c|c|c|c|}
\hline Site & Jan-Apr & May-Aug & Sep-Dec \\
\hline 1 & 7.75 & 8.1 & 7.7 \\
\hline 2 & 7.8 & 7.8 & 7.8 \\
\hline 3 & 7.2 & 7.6 & 7.4 \\
\hline 4 & 7.2 & 7.5 & 7.3 \\
\hline 5 & 7.6 & 7.8 & 7.4 \\
\hline 6 & 7.1 & 7.3 & 7.3 \\
\hline
\end{tabular}

Table 3: Monthly Variation in DO

\begin{tabular}{|c|c|c|c|}
\hline Site & Jan-Apr & May-Aug & Sep-Dec \\
\hline 1 & 8.3 & 6.2 & 7.5 \\
\hline 2 & 8.5 & 7 & 8.2 \\
\hline 3 & 6.9 & 7.3 & 7.9 \\
\hline 4 & 9.3 & 8.2 & 8.5 \\
\hline 5 & 6.4 & 6.5 & 7.2 \\
\hline 6 & 8.2 & 8 & 7.6 \\
\hline
\end{tabular}

The lowest value of BOD ware observed 0.07 $\mathrm{mg} / \mathrm{L}$ and highest were $5.5 \mathrm{mg} / \mathrm{L}$. The seasonal value varied from 3.82 to $5.02 \mathrm{mg} / \mathrm{L}$ at site I, 4.77 to $5.55 \mathrm{mg} / \mathrm{L}$ at site II, 2.07 to $4.60 \mathrm{mg} / \mathrm{L}$ at site III, 0.325 to 0.57 at site IV, 0.65 to $1.0 \mathrm{mg} / \mathrm{L}$ at site $\mathrm{V}$ and 0.07 to $0.15 \mathrm{mg} / \mathrm{L}$ at site VI (Table 4).

Table 4: Monthly Variation in BOD

\begin{tabular}{|c|c|c|c|}
\hline Site & Jan-Apr & May-Aug & Sep-Dec \\
\hline 1 & 5.01 & 4.7 & 3.8 \\
\hline 2 & 5.6 & 5.2 & 4.8 \\
\hline 3 & 3.6 & 4.6 & 2.1 \\
\hline 4 & 0.4 & 0.7 & 0.6 \\
\hline 5 & 0.6 & 1 & 0.7 \\
\hline 6 & 0.1 & 0.2 & 0.2 \\
\hline
\end{tabular}

The total alkalinity of water were recorded from a maximum of $382 \mathrm{mg} / \mathrm{l}$ at site I in the month of May -Aug and a minimum of $129.5 \mathrm{mg} / \mathrm{L}$ of site six in the month of Jan-Apr. The mean value ranged from $264.25 \mathrm{mg} / 1$ to 382 $\mathrm{mg} / \mathrm{L}$ at site I, 260.25 to $317.7 \mathrm{mg} / \mathrm{L}$ at site II, 162 to 22415 $\mathrm{mg} / \mathrm{L}$ at site III, 141 to $194 \mathrm{mg} / \mathrm{L}$ at site IV, $140-25$ to $208.56 \mathrm{mg} / \mathrm{L}$ at site $\mathrm{V}$ and 129.5 to $155 \mathrm{mg} / \mathrm{L}$ at site $\mathrm{VI}$ (Table 5).

Table 5: Monthly Variation in Total Alkalinity

\begin{tabular}{|c|c|c|c|}
\hline Site & Jan-Apr & May-Aug & Sep-Dec \\
\hline 1 & 300 & 357 & 264 \\
\hline 2 & 268 & 331 & 260 \\
\hline 3 & 182 & 162 & 225 \\
\hline 4 & 141 & 165 & 194 \\
\hline 5 & 140 & 178 & 189 \\
\hline 6 & 130 & 150 & 155 \\
\hline
\end{tabular}

The total acidity of water were recorded from a maximum of $28.75 \mathrm{mg} / \mathrm{L}$ at site II in the month of May-Aug a minimum of $7,8 \mathrm{mg} / \mathrm{L}$ at site VI in the month of MayAug. the mean seasonal value ranged from 10.25 to 27.37 $\mathrm{mg} / \mathrm{L}$ at site I, 9.85 to $28.75 \mathrm{mg} / \mathrm{L}$ at site II, 7.17 to 11.82 $\mathrm{mg} / \mathrm{L}$ at site III, 8.05 to $10.15 \mathrm{mg} / \mathrm{L}$ at site IV, 8.15 to 11.87 $\mathrm{mg} / \mathrm{l}$ at site $\mathrm{V}$ and 7.5 to $9.65 \mathrm{mg} / \mathrm{L}$ at site VI. (Table 6).

Table 6: Monthly Variation in Total Acidity

\begin{tabular}{|c|c|c|c|}
\hline Site & Jan-Apr & May-Aug & Sep-Dec \\
\hline 1 & 10.2 & 27.2 & 16.3 \\
\hline 2 & 9.8 & 28.7 & 20.8 \\
\hline 3 & 7.2 & 10.8 & 9.3 \\
\hline 4 & 8 & 9.6 & 10.2 \\
\hline 5 & 8.2 & 10.2 & 11.9 \\
\hline 6 & 8.4 & 7.5 & 9.8 \\
\hline
\end{tabular}

\section{DISCUSSION}

Temperature may not be that important factor because of the wide range of temperature tolerance of aquatic biota in non polluted environment, but in the polluted river water, rapid temperature changes may cause over shoots in the metabolism of the aquatic organisms and it may have a profound effect on dissolved oxygen and biochemical oxygen demond which subsequently effects the aquatic biota of an ecosystems. With increasing water 


\section{SINGH: PHYSICO-CHEMICAL QUALITY OF POTABLE WATER OF VARANASI CITY OF...}

temperature solubility of oxygen is reduced causing deoxygenation. During May August water temperature was higher because of low water level, low velocity, clear atmosphere and greater solar radiation and minimum water temperature during January-April and September-December months, can be explained on the basis of high percentage of humidity, frequent clouds, high current velocity and high water levels (Vyas, 1968). It was observed earlier that the temperature in the river Ganga in Varanasi ranges between 17.5-33.0 $0^{\circ} \mathrm{C}$ (Shukla et al., 1989). Evaluation of water temperature in Tiruchirapalli Corporation Water Supply shows variation from $27-29^{\circ} \mathrm{C}$ (Mohamed et al., 1999). The present study reveal that there is no wide fluctuations. The World Health Organisation (WHO) has not issued limitaion on temperature.

$\mathrm{pH}$ value is an important factor in maintaining the bicarbonate and carbonate system and is also reported to play an important role in microbial growth (King, 1982). The WHO standard for drinking water in relation to $\mathrm{pH}$ varies between 6.5-9.2. The $\mathrm{pH}$ of water of some of eastern India ranging between acidic/neutral to alkaline with ranges of average values 6.2-10.8, 6.5-7.5,7.0-8.5 (Singh and Singh, 1999), 5.9-7.9 (Rajurkar et al., 2003) and 6.4-7.6 (Hussain and Ahmad, 2002). Adak and Purohit (2000) observed that $\mathrm{pH}$ values of tap water (7.66-7.68), tubewell (7.95-8.03), open well (7.69-7.79) of Rajgangpur, Orissa was slightly alkaline. Mohamad et al., (1999) also noticed that the $\mathrm{pH}$ of corporation water supply in Tiruchirapalli varies within the permissible limit. The data of the present study showing $\mathrm{pH}$ values ranging between 7.1-8.1 throughout the year at all the sampling site indicate that these values are within the permissible limits of both WHO and ISI standards. The $\mathrm{pH}$ was noted to be in the alkaline side throughout the year within minimum mean value during the January-April and maximum during May-August at site II and I. These data also corroborate the earlier observations of Mathur et al., (1988) where the $\mathrm{pH}$ values in the river Ganga at Varanasi were in the range of 7.2-8.6.

Dissolve oxygen is one of the most important factor in water quality assessment and reflects the physical and biological processes prevailing in the natural water. Natural waters contain a number of dissolved gases of which oxygen is vital to the flora and fauna in such waters. But the amount of DO is not static. Generally, low oxygen concentrations are associated with heavy contamination by organic matter. In such condition bacteria feed on organic matter in an oxidation processes which consume DO, and when there is ample oxygen and food supply the bacteria multiply rapidly. DO is essential for the metabolism of all aquatic organisms that possess aerobic respiratory biochemistry (Wetzel, 1975 and Trivedy, 1984). During the study period, changes in oxygen content have been recorded. The general, trend of changes in dissolved oxygen concentration in different duration is indirectly or directly governed by fluctuations of temperature and bio-chemistry oxygen demand. Higher values of DO during Jan-Apr at 4 sites the period during which the water temperature was lowest. Thaman (1966) has reported low solubility of oxygen at higher temperature which is also in close accordance with the present study. Such types of situation were clearly seen in case of Ganga samples. Honnan (1979), Kudisia and Verms, 1985, Sigh and Singh 2003 also observed similar changes.

Variation in the values of BOD appeases to be a function of changes in the degree of dilution, quantity of organic matter and the activities of micro organisms carrying out decomposition of carbonaceous and nitrogenous matters. Present studies shaved higher values of BOD during Jan-Apr at site I and II (Ganga water) and lower during Sep-Dec. The highest values of BOD may be attributed to the maximum biological activity at elevated temperatures, where as the lowest indicated lower biological activity. Similar observation were made by Rai (1978), Rao et al., (1985), Sengar et al., (1985), Shukla et al., (1988), Sharma and Rajput (1996). The BOD value of Site III, IV, V and V ranges from $0.1 \mathrm{ml} / \mathrm{L}-4.6 \mathrm{mg} / \mathrm{L}$. The elevated level of BOD at site III (well water) is due to bathing activity and leakage of wastewater into well. However, BOD values of present study are within the standards prescribed by WHO $(6.0 \mathrm{mg} / \mathrm{L})$. Similar observation was recorded by Mohamad et al., (1999), Rao et al., (2001).

Acid contribute to corrosiveness and influence chemical reaction rates, chemical speciation and biological processes. In the present study, two peaks, first during MayAug and the second during Sep-Dec were observed. Gowd and Kotalah (1999), Abasi and Vinithan (1999) found the similar result. It is due to presence of strong mineral acids and weak bases. The acidity was recorded to be high at site I, II, and III, it is due to high pollution load at these sites. Addition of waste water having acidity producing substance also increases acidity of water. The values of total alkalinity 
SINGH: PHYSICO-CHEMICAL QUALITY OF POTABLE WATER OF VARANASI CITY OF...

showed some fluctuations from site to site. Maximum value were recorded for sites I, II and III probably due to the input of domestic sewage and other activities near sites. Similar results were found by Abbasi et al., (1996), Howland et al., (2000) and Adak and Purohit (2000). Highest desirable limit of alkalinity concentration for drinking water is specified as $200 \mathrm{mg} / 1$ (ISI, 1991). The alkalinity content in water for site IV, V and VI showed that values are found to be within the desirable range as per ISI. Similar result were recorded by Abbasi et al., (1996), Abbasi and Vinithan (1999), Gowd and Kotalah (1999), Swamy et al.,(1999), Rao et al.,(2001), Hussain and Ahmad (2002), and Rajurker et al., (2003).

It was also observed that maximum alkalinity was found during May-Aug followed by Jan-Apr and Sep-Dec for most of the sites. Similarily Gowd and Kotalah (2000) reported maximum alkalinity during the months before on sets of rains. Rajurkar et al., (2003) found the similar result. The high value of alkalinity may results from waste discharge and accumulation of fatty acids propionates, acetates etc. The latter are generated as products of microbial decomposition of organic matter present in the water body.

\section{CONCLUSIONS}

It was observed that the temperature of the water changed throughout the year from 18 to $30^{\circ} \mathrm{C}$. At site I and II, $\mathrm{pH}$ showed maximum fluctuation probably because of discharge of domestic and industrial sewage. During the month of Jan-Apr the lowest Dissolved Oxygen was observed at site $\mathrm{V}$ while it was highest at site IV. The high values of biochemical oxygen demand (BOD) were recorded at site II and I due to high organic load. The total alkalinity of water was recorded maximum for site I during the month of May -Aug and minimum for site VI during Jan-Apr. The total acidity of water during the month of May-Aug was recorded maximum for site II and minimum for site VI. It is well known fact that physicochemical studies are unable to explain fully completed problems of water pollution.

\section{ACKNOWLEDGEMENT}

We are highly indebted to the Head, Department of B. H. U. for providing me the lab and library facilities for the present investigation.

\section{REFERENCES}

Abbasi S.A., Arya D.S., Hameed A.S. and Abbasi N., 1996. Water quality of a typical river of Kerala, 15(2):163-166.

Abbasi S.A. and Vinithan S., 1999. Water quality in and around on industrialized suburb of Pondicherry, 41(4): 253-263.

Adak, Dasgupta M. and Purohit, 2000. Correlation coeffcient of some physico-chemical characteristics of surface and ground water of Rajganpur: Part-1. IJEP, 20(9): 681-687.

APHA, 1985. Standard methods for the examination of water and wastewater, $16^{\text {th }}$ ed. American Public Health Association, Inc. Washington, D.C.

Balasankar T. and Nagarajan S.A., 1999. Correlation study on Physico-chemical characteristics of ground water in and around Cuddalore SIPCOT, Tamil Nadu. IJEP, 20(6):427-429.

Barbaras S., 1986. Monitoring natural waters for drinking water quality. WHO Stat. Q., 39: 32-45.

David A., 1959. "Effect of Calcutta sewage upon the fisheries of the Kulti estuary and connected fisheries. J. Asiatic Soc. Bengal (New Series) 1: 336-63.

Dagankar A. and Saksena D.N., 1992. Physico-chemical and biological characterization of Rample tank, Kalia Sagar, Gwalior, J. Hydrobiology, 8: 11-19.

Dasgupta, Adak M. and Purohit K.M., 2000. Correlation coefficient of some physico-chemical characteristics of surface and ground waters of Rajgangpur: Part-I, IJEP, 20(9): 681-687.

Deshmukh S.B., Phadke N.S. and Kothandaraman V., 1964. Physico-chemical characteristics of Kanhan river water, Nagpur city, Environ. Hlth., 6(3): 181.

Dwivedi S., Tiwari I.C. and Bhargava D.S., 2000. Classification of water quality of river Ganga at Varanasi. IJP, 20(9): 688-697.

Ganpati S.V. and Alikunhi K.H., 1950. Factory effluent from the mettar chemical and industrial corporation Ltd. Mettar Dam, Madras and their 
pollutional effects on the fisheries of the river Kavvery. 16(3): 183.

Ganpati S.V. and Chacko P.I., 1957. Investigation of the river Godavari; and effect of the paper mill pollution at Rajahmundri. Proc. Indo. Pacific. Fish. Committee, Madras, 2 \& 3: 70.

Gowd S.S. and Kotalah B., 1999. Seasonal variation of water quality in tropical Kalyani reservoir, near Triputi. IJEP, 20(6): 452-455.

Hazen T.C., Fliermanns C.B., Hirsch R.F. and Esch G.W., 1978. Prevalence and distribution of Acromonas hydrophila in the United States. Appl. Environ. Microbiol., 36: 731-738.

Honnan H., 1979. Chemical modification in reservoir regulated streams in the ecology of regulated streams. J.W. Ward and J.A. Standford editin. Plenum corporation publication, 75-94.

Howland R.J.M., Tappin A.D., Uncles R.J., Plummer D.H. and Bloomer N.J., 2000. Distributions and seasonal variability of $\mathrm{pH}$ and alkalinity in the Tweed Estuary, U.K., The Sci. of the total Environ., 251/252: 125-138.

Hussain M.F. and Ahmad I., 2002. Variability in physicochemical parameters of Pachin river (Itanagar). Indian J. Environ Hlth, 44/4: 329-336.

Kannan N. and Rajasekaran N., 1991. Correlations of water quality parameters of printing Industry effluents in Sivakasi (South India). Indian J. Env. Health, 33(3): 330-335.

King D.L., 1982. Carbon limitation in sewage lagoons. In : Nutrients and Eutrophication. A limiting nutrient controversy (ed. G.E. Likens). Amr., Soc., Limnology Oceanger. Allen pressure, Lawrence, Kansas: 98-112.

Khatri T.C., 1985. Physico-chemical feature of Idukki reservoir, Kerala. During pre-monsoon period. Enciron. \& Ecol., 3: 134-137.

Kudesia V.P and Sharma, 1981. Detection of trace elements in Kali Nadi water in Meerut, IAWPC Tech. Annual, VIII : 168.
Kudesia V.P. and Verma S.P., 1985. A studay of industrial pollution on Kali river. J. Evin. Sc., 1(2).

Kumar A., Kumari P. and Singh L.K., 2002. Eco-strategies of water management in India. In: Ecology of Polluted Water (Ed. A. Kumar). Ashish Publ. House, New Delhi, 597-619.

Mathur A., Prasad S. and Rupainwar D.C., 1988. Pollution of river Ganga by heavy metals in Varanasi city region. I.A.W.P.C. Tech. Annual, 15: 139-145.

Mohamed H.E. Syed, Hameed P. Shahul, Masilamani V., Ravikumar S. and Somasundaram S.S.N., 1999. Evaluation of water quality in Tiruchirapalli corporation water supply. IJEP, 20(3):194-199.

Motwani M.P., Banerji S.M. and Karamchandani S.J., 1956. Some observation on the pollution of the river Sone by the factory effluent of the Rolitas industries at Dalmianagar (Bihar) India. J. Fish, 3: 334-367.

Nagarajan S., Swaminathan M. and Sabarathihan P.L., 1992. A correlation study on physico-chemical characteristics of groundwater in and around Chidambaram town, Tamil Nadu. Poll. Res., 12(4): 245-250.

Palmer C.M., 1969. A composite rating of algae tolerating organic pollution. Journal of Pyhcology, 5: 78-82.

Rajgopalan S., Basu A.K., Dhaneshwar R.S. and Rao C.S.G., 1970. Pollution of river Subarnrekha at Ranchi - A survey, Environ. Hlth., 12: 246.

Rajurkar N.S., Nongbri B. and Patwardhan A.M., 2003. Physico-chemical and biological investigations of river Umshyrpi at Shillong, Meghalaya. Indian J. Environ. Hlth., 45(1): 83-92.

Rai Hand Hill G., 1978. Bacteriological Studies on Amazonia, Mississippi and Nile water. Arch. Hydrobiol., 81(4): 445-461.

Rao K.S., Dad N.K. and Pandya S.S., 1985. Community structure of Benthic macroinvertitrates and their utility as indicators of pollution in river. Khon (Indore) India. Proc. Nat. Symp. Pure and Appl. Limno Ced, Adoni. A.D. Bull. Bot. Soc., Sagar 32: 114-119. 


\section{SINGH: PHYSICO-CHEMICAL QUALITY OF POTABLE WATER OF VARANASI CITY OF...}

Rao A.V., Jain B.L. and Gupta I.C., 1993. Impact of textile industrial effluents on agricultural land-A case study. Ind. Jour. Environ. Hlth., 35(2): 132-138.

Rao A.S., Rao P.R. and Rao N.S., 2001. Quality of drinking water from ponds in villages of Kolleru lake Region, 43(1): 45-52.

Ray P., Singh S.B. and Sehgal K.L., 1966. A study of some aspects of ecology of the river Yamuna and Ganga at Allahabad (U.P.) in 1958-59, Proc. Natn. Acad. Sci., 36B(3): 235.

Sangu R.P.S., Pathak P.D. and Sharma K.D., 1984. Monitoring of Yamuna river water at Agra, River Ecology and Human Health, R.S. Ambasht and B.B. Tripathi (eds.), Nat. Env. Cons. Asson., 39.

Sengar R.M.S., Sharma K.D. and Pathak P.D., 1985. Studies on distribution of algae flora in polluted and non polluted regions in Yamuna river at Agra (U.P.). J. Indian, Bot. Soc., 64: 365-376.

Sharma A. and Rajput S., 1996. Incidence and multiplication of Acromonads in river Narmada at Jabalpur in relation to its hygienic significance. Indian J. Environ. Health, 38(4): 298-302.

Shukla S.C., Tripathi B.D. and Prasad N., 1988. Physicochemical and bacteriological characteristics of river Varuna at Varanasi. The Journal of Scientific Research, B.H.U., 38: 133-141.

Singh A.K. and Bhowmick B.K., 1985. Effect of sewage on physico-chemical characteristics and bacterial population of river Ganga at Patna. Indian J. Eco., 12(1): 17-19.
Singh A.P. and Singh J., 2003. Physico-chemical characteristics of river Ami in relation to discharge of paper mill effluent. Indian J. Environ. Hlth., 45(2), 93-96.

Singh T.B., Bala I. and Singh D., 1999. Assessment of groundwater quality of Paonta Sahib (H.P.). Poll. Res., 18(1): 114-114.

Swamy N. Kumara, Subramanyam B. and Kotalah B., 1999. Assessment of Ground water pollution in and around a solid waste disposal sites $-\mathrm{A}$ case study. IJEP, 20(3):206-208.

Trivedy R.K. and Goel P.K., 1984. Chemical and biological methods for water pollution studies. Environmental publications, Karad.

Trivedy R.K., 1988. Ecology and pollution of Indian Rivers, Ashish Publishing House, New Delhi, 1443.

Verma S.R. and Mathur R.P., 1971. Characteristics and pollutional effect of paper mills wastes on the Hindon river. Seminar on water supply and sanitation problems of urban areas. Institute of Engineers, Roorkee Sub-centre, India 2, E.4.

Vyas L.N., 1968. Studies in phytoplankton ecology of Picchola lake, Udaipur. Pro. Symp. Recent Adv. Trop. Ecol., 334-347.

Wetzel R.G., 1975. Limnology. W.B. Saunders co, Philadelphia, U.S.A. 743.

World Health Organization, 1984. Guidelines for Drinking Water Quality. Recommendations, 1:130. 